\section{Rediscovery of the Banded Krait Bungarus fasciatus (Schneider 1801) (Serpentes: Elapidae) from Warangal District, Andhra Pradesh, India}

\section{Srinivasulu ${ }^{1}$, D. Venkateshwarlu ${ }^{2} \&$ M. Seetharamaraju ${ }^{3}$}

${ }^{1,3}$ Wildlife Biology Section, Department of Zoology, University College of Science, Osmania University, Hyderabad, Andhra Pradesh 500007, India

${ }^{2}$ Shankarajpalli, Eturnagaram, Warangal District, Andhra Pradesh 506165, India

Email: hyd2masawa@gmail.com ${ }^{1}$

The Banded Krait Bungarus fasciatus (Schneider 1801) is one of eight species of kraits in India. The generic nomen, which is the Latinized rendering of the local name "Bangarum Pamah" (meaning golden snake) by which the Banded Krait is known by the Telugu speaking natives of Orissa (Russell 1796), was erected by Daudin in 1803 (Boulenger 1890; Wall 1912). It ranges from South Asia (parts of peninsular India and northeast India) to Southeast Asia (whole of Indo-Chinese region from Myanmar to Malaysian peninsula and archipelago, Wall 1912; Smith 1943). In India, its range includes the northeast, West Bengal, Orissa, parts of Maharashtra, Bihar, Jharkhand, Madhya Pradesh, Chhattisgarh and Andhra Pradesh (Wall 1912; Kinnear 1913; Smith 1943; Sanyal et al. 1993; Das 2002; Sharma 2003; Whitaker \& Captain 2004).

The Banded Krait is easily recognizable by a combination of characters: the distinct equal-width alternating bands of canary yellow or buff, and black or purplish-black on a body that is distinctly triangular in cross-section, and by its blunt, rounded tail tip. Fully grown adults average around five feet six inches and rarely grow up to six to seven feet in length (Smith 1911). The head is not broader than the neck; the body is smooth and glossy. Each coloured band completely encircles the body and involves five to seven scales in the length. The head is black with an inverted yellow ' $\mathrm{V}$ ' and the chin and throat are yellow (Wall 1912; Smith 1943; Das 2002; Sharma

Date of online publication 26 June 2009

ISSN 0974-7907 (online) | 0974-7893 (print)

Editor: Ashok Captain

\section{Manuscript details:}

Ms \# 01986

Received 28 April 2008

Final received 12 March 2009

Finally accepted 04 June 2009

Citation: Srinivasulu, C., D. Venkateshwarlu \& M. Seetharamaraju (2009) Rediscovery of the Banded Krait Bungarus fasciatus (Schneider 1801) (Serpentes: Elapidae) from Warangal District, Andhra Pradesh, India. Journal of Threatened Taxa 1(6): 353-354.

Copyright: (C) C. Srinivasulu, D. Venkateshwarlu \& M. Seetharamaraju 2009. Creative Commons Attribution 3.0 Unported License. JoTT allows unrestricted use of this article in any medium for non-profit purposes, reproduction and distribution by providing adequate credit to the authors and the source of publication

\section{OPEN AGCESS | FREE DOWNLOAD (C) (7) (口)}

2003; Whitaker \& Captain, 2004).

From Andhra Pradesh, the Banded Krait has been reported from Narsampet $\left(17^{\circ} 55^{\prime} \mathrm{N} \& 79^{\circ} 54^{\prime} \mathrm{E}\right)$, Warangal District based on a single specimen that was shot by Mr. G.E.C. Wakefield on 26 December 1912 while it was swimming in a stream (Kinnear 1913). This locality is the southernmost limit of the Banded Krait's range in Peninsular India (Smith 1943; Sanyal et al. 1993; Sharma 2003; Whitaker \& Captain 2004). Through this communication we put on record the re-sighting of the Banded Krait in Warangal district, Andhra Pradesh after a gap of 95 years, about 70 kilometers north northwest of Narsampet.

We had been studying wildlife of forested tracts of Warangal District, Andhra Pradesh since 1996 and failed to encounter either living or dead specimen of Banded Krait until November 2006, when it was first sighted by the second author while it was crossing the road at dusk near Roheer in Eturnagaram Wildlife Sanctuary. After that we came across dead specimens of Banded Krait on three occasions in Eturnagaram Wildlife Sanctuary from November 2006 to November 2007 (Image 1). The first specimen was killed by local cowherds on November 8, 2006 near eight kilometer milestone on Eturnagaram to Roheer Road. Enquiries with the locals revealed that they had never seen this kind of snake and believed it might have migrated from elsewhere along the Godavari. The second specimen, a road kill, was observed on July 25, 2007 about six kilometers from Eturnagaram on the same road. The third specimen, again a road kill, was observed on August 5, 2007 five kilometer from Eturnagaram on the same road. We collected the intact head of the last specimen (Images 2 \& 3) and deposited it as voucher specimen in the Natural History Museum of Osmania University, Hyderabad (Reg.No. NHM.OU.REP.4-2007).

The Banded Krait has been noted to show affinity for damp places in open tracts of country, grasslands, crops or low sparse jungles (Wall 1912). All our observations are from the vicinity of water bodies in Eturnagaram Wildlife Sanctuary. The first live specimen was sighted about five hundred meters from where the first dead specimen was observed in November 2006. The place where it was sighted moving slowly underneath a Randia dumetorum bush is located in the mixed teak forested tract about one kilometer east of Jampanna Vagu (a perennial stream) and two kilometers west of the Godavari River. The second and third specimens were sighted near Butaram Tank adjacent to croplands. The habitat here is characterized by dense undergrowth with Terminalia arjuna and Butea monosperma trees. The adjacent croplands have artisan wells and water is present in the wells and other natural water bodies throughout the year.

The Banded Krait is partial to an ophidian diet (Wall 1912) and has been reported to feed on rat snakes, tree snakes, checkered keelback, buff-striped keelback, cobra, grass snake (Primrose 1899), python, vine snakes, lizards, frogs and fish (Wall 1912; Daniel 2002; Das 2002; Whitaker \& Captain 2004). The third specimen that we encountered had fed on Buffstriped Keelback Amphiesma stolatum (Image 2).

Based on these recent observations and evidence, we put on record the presence of the Banded Krait in Eturnagaram Wildlife Sanctuary and confirm its presence in Warangal 


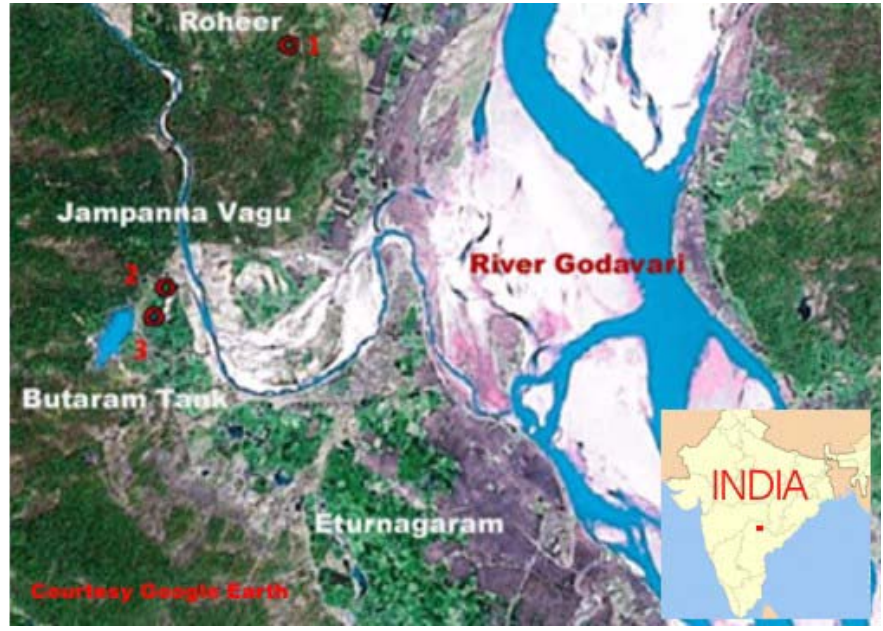

Image 1. Map depicting sites in Eturnagaram Wildlife Sanctuary from where Banded Krait were encountered

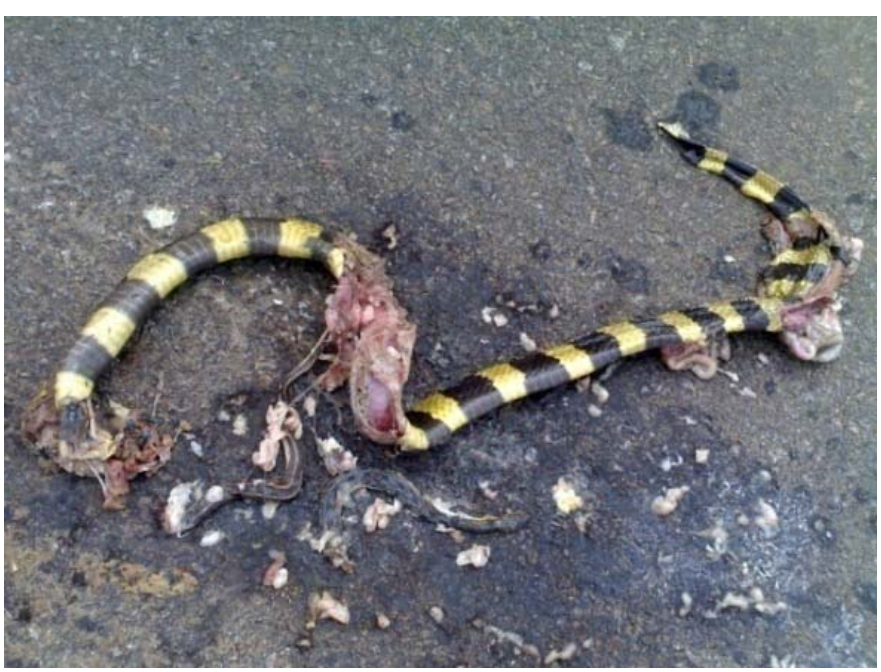

Image 2. Road kill of Banded Krait in Eturnagaram Wildlife Sanctuary

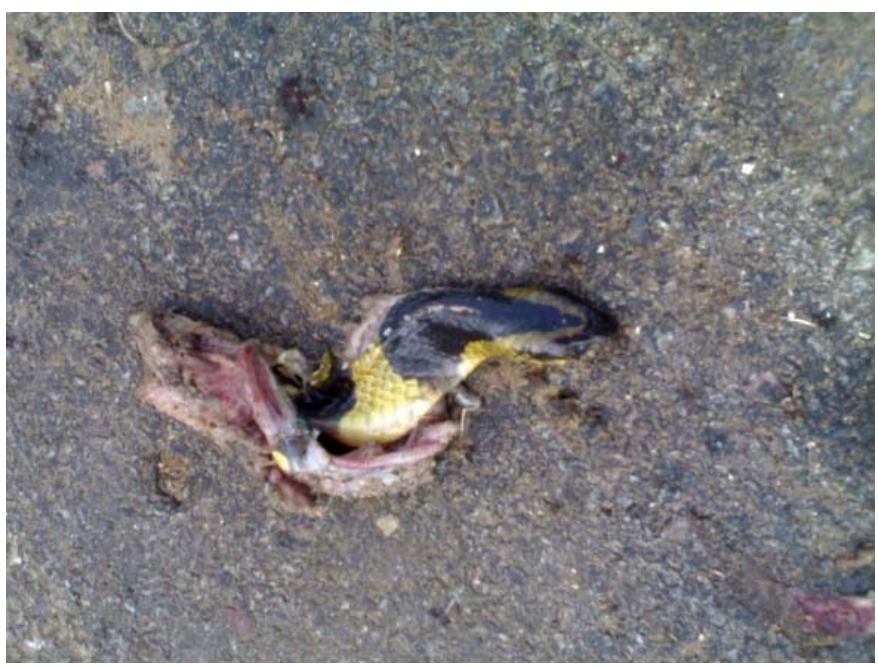

Image 3. Road kill (head) of Banded Krait in Eturnagaram Wildlife Sanctuary district of Andhra Pradesh after about 100 years of its first report. Owing to the misinterpretation of a previous locality record from Andhra Pradesh (then Hyderabad State), many authors have reported its range to be 'as far south as Hyderabad' (Wall 1912; Martin 1913; Daniel 2002; Sharma 2003). Hyderabad $\left(17^{\circ} 23^{\prime} \mathrm{N} \& 78^{\circ} 29^{\prime} \mathrm{E}\right)$, the state capital of Andhra Pradesh, is located about $187 \mathrm{~km}$ southwest of Narsampet as the crow flies, and we urge future researchers to quote Narsampet as the southern most record of this species from peninsular India. As this species is of timid nature, it becomes an easy prey to human indifference as well as vehicular movement, thus we recommend that the State Forest Department should take necessary steps to put up warning signs on roads cautioning drivers not to run over crossing snakes and educate local villagers about the ecological importance of this species. These steps would ensure the survival of the Banded Krait Bungarus fasciatus (Schneider 1800) in Eturnagaram Wildlife Sanctuary, Andhra Pradesh.

\section{References}

Boulenger, G.A. (1890). The Fauna of British India, including Ceylon and Burma. Reptilia and Batrachia. Taylor and Francis, London, xviii + $541 \mathrm{pp}$.

Daniel, J.C. (2002). The Book of Indian Reptiles and Amphibians. BNHSOxford University Press, Mumbai, viii + 238pp.

Das, I. (2002). A Photographic Guide to Snakes and other Reptiles of India. New Holland Publishers (UK) Ltd, London, 144pp.

Kinnear, N.B. (1913). Banded Krait (Bungarus fasciatus) in Hyderabad State. Journal of the Bombay natural History Society 22: 635-636.

Martin, S.J. (1913). Banded Krait (Bungarus fasciatus) in Oudh. Journal of the Bombay natural History Society 22: 635

Primrose, A.M. (1899). Food of the King Cobra and Krait. Journal of the Bombay natural History Society 12: 589.

Russell, P. (1796). An account of Indian serpents collected on the coast of Coromandel; containing descriptions and drawings of each species, together with experiments and remarks on their several poisons. London, 90pp +44 coloured plates.

Sanyal, D.P., B. Datta Gupta \& N.C. Gayen (1993). Reptilia. pp. 1-64. In: Director, ZSI (ed.) Fauna of Andhra Pradesh, Part I (Reptilia, Amphibia and Fishes), Zoological Survey of India, Calcutta.

Sharma, R.C. (2003). Handbook - Indian Snakes. Zoological Survey of India, Kolkata, xx $+292 \mathrm{pp}$

Smith, M.A. (1943). The Fauna of British India Ceylon and Burma, including the whole of Indo-Chinese sub-region. Reptilia and Amphibia, Vol. III, Serpentes. Taylor and Francis, London, xii + 583pp.

Smith, O.A. (1911). Large Common and Banded Kraits. Journal of the Bombay natural History Society 21: 283-284.

Wall, F. (1912). A popular Treatise on the Common Indian Snakes. Part 15. Bungarus fasciatus and Lycodon striatus. Journal of the Bombay natural History Society 20: 933-953.

Whitaker, R. \& A. Captain (2004). Snakes of India, The Field Guide. Draco Books, Chennai, $481 \mathrm{pp}$. 